\title{
Concentrated whey from block freeze concentration or milk-based ice creams on Bifidobacterium BB-12 survival under in vitro simulated gastrointestinal conditions
}

\author{
Eulália Lopes da Silva BARROS ${ }^{1}$, Callebe Camelo SILVA ${ }^{1}$, Silvani VERRUCK ${ }^{2}$, Maria Helena Machado CANELLA², \\ Bruna Marchesan MARAN ${ }^{1}$, Erick Almeida ESMERINO ${ }^{3}$, Ramon SILVA ${ }^{3}$, Elane Schwinden PRUDENCIO ${ }^{1,2 *}$ (D)
}

\begin{abstract}
This study's main highlight refers to the utilization of concentrated whey, obtained from freezing concentration processes in ice cream manufacturing. The second important point refers to the comparison between dairy and whey concentrated ice creams' Bifidobacterium BB-12's protective effects under in vitro simulated gastrointestinal conditions. Both ice cream types showed bifidobacteria viable cell counts higher than the recommendation for a product to be considered a probiotic. The incorporation of such bacteria into both ice cream varieties showed the most important probiotic characteristic, which is survivability. Bifidobacterium BB-12 demonstrated survival rates higher than $90 \%$ after the upper digestive tract passage into the colon. In addition to that, the best protective effect was pointed out from whey-based ice cream testing. Considering such statements, the addition of probiotic bacteria and concentrated whey on ice cream manufacturing could be decisive when producing functional foods, providing benefic effects on the consumer.
\end{abstract}

Keywords: block freeze concentration; probiotic ice cream; whey; concentration; gastrointestinal simulation.

Practical Application: Usage of concentrated whey's instead of milk in to develop functional ice creams.

\section{Introduction}

Ice cream has been described as a complex frozen colloid, consisting of a continuous aqueous phase with ice crystals dispersed in a semi-frozen solution (Akbari et al., 2019; Saremnezhad et al., 2020). The original ice cream formulation consists on milk and, in some cases, functional elements. Replacing milk with concentrated whey obtained through freezing concentration processes was not yet described on ice cream production.

Cheese whey is a liquid obtained from precipitated casein removal in cheese-making processes (Remón et al., 2016). According to Hausjell et al. (2019), around 190 million tons of cheese whey is generated yearly worldwide, causing great environmental impact. The volume of effluents produced by the cheese industry is directly proportional to its market demand. Considering mass production, one kilogram of cheese requires roughly 10 kilos of milk and yields nine kilograms of whey. Cheese whey is a byproduct that represents significant environmental impact due to its physicochemical composition, comprehending $\beta$-lactoglobulin, $\alpha$-lactalbumin, immunoglobulin, serum albumin and lactoferrin. On the other hand, such effluent is rich in nutrients and cannot be simply discarded into the environment without adequate treatment (Prazeres et al., 2012; Hausjell et al., 2019). Due to its low solids rate, concentration techniques can be applied to facilitate its usage and further processing. As an example, thermal evaporation under vacuum systems is typically employed and results in undesirable sensorial and nutritional changes in the byproduct (Menchik \& Moraru, 2019). Thus, liquids' non thermal concentration processes, including block freeze concentration, have been gaining interest in the past few years. This process is based on water's fractional crystallization into ice and its sequential separation from the concentrated liquid through gravitational thawing (Petzold et al., 2015). Petzold et al. (2015) reported advantages on the process, such as a simple separation step and sensible food components reduction. Block freezing concentration is considered an environmentally friendly technology, with high effectiveness and low energy consumption. Also, it preserves the product's sensorial and nutritional qualities and doesn't require expensive maintenances (Aider \& Halleux, 2008). Muñoz et al. (2018a) stated that the energy required on freezing concentration processes is relatively low when compared to evaporation and other water removal techniques.

The usage of concentrated whey instead of milk on fermented milk beverages' production was successfully reported by Canella et al. (2018). Silva et al. (2015) stated that, despite the fact that dairy production represents one of the most developing segments and a major branch of the functional food industry, further studies are required on functional ice creams. Probiotics are considered functional, since they present live microorganisms that provide health benefits, such as intestinal 
microbiota maintenance, when consumed regularly (Hill et al., 2014). Bifidobacterias are the most common probiotic species within normal human intestinal tract (Hadad et al., 2019). The probiotic strain Bifidobacterium animalis subsp. lactis BB-12 (BB-12) shows benefic effects on human's gastrointestinal health and immune system (Liu et al., 2020). Some studies have pointed ice cream as a great probiotic bacteria carrier (Champagne et al., 2015; Akalin et al., 2018; Balthazar et al., 2018; Calligaris et al., 2018; Góral et al., 2018), however, Kozłowicz et al. (2019) defends that the ice cream composition can lead to serious damages on probiotic bacteria cells. Thus, probiotic microorganisms should survive not only during food processing, but also through gastrointestinal flow (Soares et al., 2019). The integrity of the cell membranes, intracellular $\mathrm{pH}$ and functional enzymes of probiotic cells can be constantly challenged by stressful factors such as gastric acidity, biliary acids and digestive enzymes during their way through the digestive tract (Rodrigues et al., 2019). Therefore, studies should focus on how probiotic cells respond to all in vitro gastrointestinal conditions. Gastric and biliary acids play an important role on body defenses against ingested microorganisms, killing and controlling gastrointestinal exposure to many pathogens. However, this same defense mechanism can also disable potentially beneficial microbes, such as probiotics. Considering probiotic effects that depend on the viability and intestinal physiological activity, the probiotic's survival in gastric and biliary acids of the upper gastrointestinal tract is a critical point (Jungersen et al., 2014). Therefore, the usage of concentrated whey instead of milk in ice cream elaboration was reported as a suitable way to develop functional ice creams. This study's objective was to enhance concentrated whey's usage on probiotic ice creams production, considering its high availability and lower cost, as well as evaluating bifidobacterial survivability to different in vitro simulated gastrointestinal environments.

\section{Material and methods}

\subsection{Materials}

Two ice creams were manufactured using $61.70 \mathrm{~g} / 100 \mathrm{~g}$ of pasteurized whole milk (12.03 g/100g of total solids) (Papenborg, Biguaçu, Brazil) and concentrated whey $(18.61 \mathrm{~g} / 100 \mathrm{~g}$ of total solids) obtained from block freeze concentration process at its second stage, respectively. The block freeze concentration process is based on the complete freezing of whey, followed by a partial defrosting procedure under simple gravitational separation. Once the whey was frozen, $50 \%$ of the initial volume was defrosted at room temperature $\left(20 \pm 2{ }^{\circ} \mathrm{C}\right)$, resulting in two fractions denoted as concentrated whey and ice. The composition of both ice creams 1 (made of whole milk) and 2 (made of concentrated whey) consisted on $16.03 \mathrm{~g} / 100 \mathrm{~g}$ of cream with $45 \mathrm{~g} / 100 \mathrm{~g}$ of fat content (Tirol, Treze Tílias, Brazil); $0.06 \mathrm{~g} / 100 \mathrm{~g}$ of sodium chloride (Ciasal, Areia Branca, Brazil) and; $22.21 \mathrm{~g} / 100 \mathrm{~g}$ of sucrose (Camil, São Paulo, Brazil). A probiotic strain of Bifidobacterium BB-12 (Bifidobacterium animalis subsp. lactis, Chr. Hansen, Honsholm, Denmark) was added at end of the process. In vitro simulated gastrointestinal conditions required the usage of the following enzymes: $\alpha$-amylase ( $28.75 \mathrm{U} / \mathrm{mg}$ protein), pepsin from porcine gastric mucosa (400 U/mg protein) and pancreatin from porcine pancreas (digestive power - 8 X USP specifications), as well as bovine bile salt (28.75 $\mathrm{U} / \mathrm{mg}$ protein), all purchased from Sigma-Aldrich (St. Louis, MO, USA). An appropriate medium containing the major compounds present in the colon (large intestine) was prepared using bacteriological peptone, yeast extract, tryptone and Tween 80, acquired from Oxoid (Hampshire, UK). To mimic colon conditions, $\mathrm{NaCl}, \mathrm{KH}_{2} \mathrm{PO}_{4}$, $\mathrm{MgSO}_{4} \cdot 7 \mathrm{H}_{2} \mathrm{O}, \mathrm{KCl}$, citrus pectin, casein, starch, and L-cysteine from Sigma-Aldrich (St. Louis, MO, USA) were used. The usage of MRS broth (Difco, Sparks, USA) provided an excellent base for bacterial strain behavior comparison. It was used as a control sample after the exposition to in vitro simulated gastrointestinal conditions, as well as during the preparation of bifidobacteria suspensions. MRS agar (Difco, Sparks, USA), sodium propionate (Fluka, Neu-Ulm, Germany), lithium chloride (Vetec, Rio de Janeiro, Brazil) and AnaeroGen (Oxoid, Hampshire, UK) were used to determine bifidobacterial viable cell counts.

\subsection{Preparation of bifidobacteria's suspensions}

Bifidobacterium BB-12's freeze-dried culture was rehydrated in sterile skimmed milk, accordingly to Fritzen-Freire et al. (2012), named stock solution, and stored in sterile bottles at $-18 \pm 2{ }^{\circ} \mathrm{C}$. Then, bifidobacteria's cell suspension was prepared accordingly to Rodrigues et al. (2011), along with modifications. The stock solution was added to the MRS broth, modified with $0.2 \mathrm{~g} / 100 \mathrm{~g}$ of lithium chloride and $0.3 \mathrm{~g} / 100 \mathrm{~g}$ of sodium propionate, and then submitted to incubation in anaerobic jars with AnaeroGen ${ }^{\circ}$ at $37 \pm 1{ }^{\circ} \mathrm{C}$ for $48 \mathrm{~h}$. After incubation, bifidobacteria cells were harvested by centrifugation $(1,000 \mathrm{x} \mathrm{g})$ (centrifuge from Nova Técnica, São Paulo, Brazil) at temperature equal to $25 \pm 1{ }^{\circ} \mathrm{C}$ during $10 \mathrm{~min}$. The supernatant was discarded and the cells were washed twice with a saline solution $(0.85 / 100 \mathrm{~g})$. Bifidobacteria cells were suspended in the following solutions: $20 \mathrm{~mL}$ of MRS broth; $20 \mathrm{~mL}$ of whole pasteurized milk and; $20 \mathrm{~mL}$ of concentrated whey. Final Bifidobacterium BB-12 viable cell counts in each suspension were $9.81 \log \mathrm{CFU} / \mathrm{mL}$ (colony-forming units per $\mathrm{mL}$ ), $10.04 \log \mathrm{CFU} / \mathrm{mL}$, and $9.64 \operatorname{logs} \mathrm{CFU} / \mathrm{mL}$, for MRS broth (control), whole milk and concentrated whey, respectively.

\subsection{Ice cream production}

The ice cream initial mix consisted on pasteurized whole milk (ice cream 1) and concentrated whey, obtained from freeze concentration process' second stage (ice cream 2). Cream, sodium chloride and sucrose were then added to both ice creams, in quantities previously described in section 2.1. Both mixes were pasteurized at $75 \pm 2{ }^{\circ} \mathrm{C}$ during $30 \mathrm{~min}$ at water bath (Model DI950M, Dist, Florianópolis, SC, Brazil); and cooled down to $4 \pm 1{ }^{\circ} \mathrm{C}$. Posteriorly, bifidobacteria's cell suspensions $(20 \mathrm{~mL} / \mathrm{L})$ were added into the ice creams. Ice creams were produced in batch freezers (Model ICE 21, Cuisinart, New Jersey, USA), stored in $100 \mathrm{~g}$ plastic containers and then hardened in the freezer before further analysis, providing three samples.

\subsection{In vitro simulated gastrointestinal experiment}

In vitro simulated gastrointestinal experiments were performed in triplicates, simulating typical conditions of different body parts such as the human mouth, esophagus, stomach, duodenum, 
ileum and colon sequentially, as established by Barretta et al. (2019) and as demonstrated in Figure 1. In the colon scenario, samples were collected at $12 \mathrm{~h}$ (ascending colon), $24 \mathrm{~h}$ (transverse colon) and $48 \mathrm{~h}$ (descending colon). The in vitro experiments were performed with $25 \mathrm{~g}$ of both 1 and 2 ice cream samples. As well as the ice creams samples, $25 \mathrm{~mL}$ of the MRS broth (control) along with $20 \mathrm{~mL} / \mathrm{L}$ of bifidobacteria's suspension was also submitted to in vitro experiment. Thus, ice cream 1, ice cream 2 and control (MRS broth) samples were evaluated under in vitro gastrointestinal conditions. Prior to its usage, all enzyme solutions were filter-sterilized through $0.22 \mu \mathrm{m}$ membrane filters (MF-Millipore, Billerica, MA, USA) and maintained on ice baths during the simulation. The temperature $\left(37 \pm 1{ }^{\circ} \mathrm{C}\right)$ and peristaltic movement intensity of the human body were simulated water baths (Model DI950M, Dist, Florianópolis, SC, Brazil). As it occurs in natural gastrointestinal conditions, the overall volume increased under in vitro gastrointestinal conditions.

\subsection{Bifidobacterium BB-12 viable cells count}

At the end of each simulated gastrointestinal stage, samples were evaluated on bifidobacteria viable cell counts. Each sample dilution was corrected with peptone water $(0.1 \mathrm{~g} / 100 \mathrm{~g})$ to $225 \mathrm{~mL} / 25 \mathrm{~g}$ of each ice cream or $225 \mathrm{~mL} / 25 \mathrm{~mL}$ of MRS broth. Samples were blended in a bag mixer 400 (Interscience, St. Nom, France), serially diluted with peptone water $(0.1 \mathrm{~g} / 100 \mathrm{~g})$ and plated in triplicates on MRS agar with lithium chloride $(0.2 \mathrm{~g} / 100 \mathrm{~g})$ and sodium propionate $(0.3 \mathrm{~g} / 100 \mathrm{~g})$, as described by Vinderola \& Reinheimer (2000). Plates were incubated in anaerobic jars with AnaeroGen ${ }^{\circ}$ at $37 \pm 1^{\circ} \mathrm{C}$ for $72 \mathrm{~h}$ and Bifidobacteria viable cell counts were carried out in triplicate and expressed as log colony-forming units per gram (log CFU/g).

\subsection{Survival rate}

Bifidobacteria's performance under in vitro conditions was calculated in survival rate (Equation 1), as described by Guo et al. (2009).

Survival rate $(\%)=\frac{\mathrm{N}_{1}}{\mathrm{~N}_{0}} \times 100$

where $\mathrm{N}_{1}$ represents Bifidobacterium $\mathrm{BB}-12$ viable cell counts ( $\log \mathrm{CFU} / \mathrm{g}$ ) after exposure to each simulated in vitro gastrointestinal stage and $\mathrm{N}_{0}$ is bifidobacteria viable cell counts (log CFU/g) before such stages.

\subsection{Data analysis}

All data was expressed considering mean \pm standard deviation of the triplicate measurements of three samples for each lot. Statistical analysis was applied through analysis of variance (ANOVA), followed by Tukey's test. Statistical significance was attributed when $P<0.05$. Results were processed in STATISTICA 13.3 (TIBCO Software Inc., Palo Alto, CA) software.

\section{Results and discussion}

Figure 2 and Table 1 shows Bifidobacterium BB-12 viable cell counts and its survival rate after being submitted to each in vitro simulated gastrointestinal stage, respectively. Both ice cream samples could be considered a good vehicle for Bifidobacterium BB-12, since the probiotic viable cell count was higher than the recommended amount for a product to be considered a probiotic. Hill et al. (2014) affirmed that a given probiotic might induce several health-promoting factors if the probiotic viable cell count is $\geq 6 \log \mathrm{UFC} / \mathrm{g}$ or $\mathrm{mL}$, enhancing

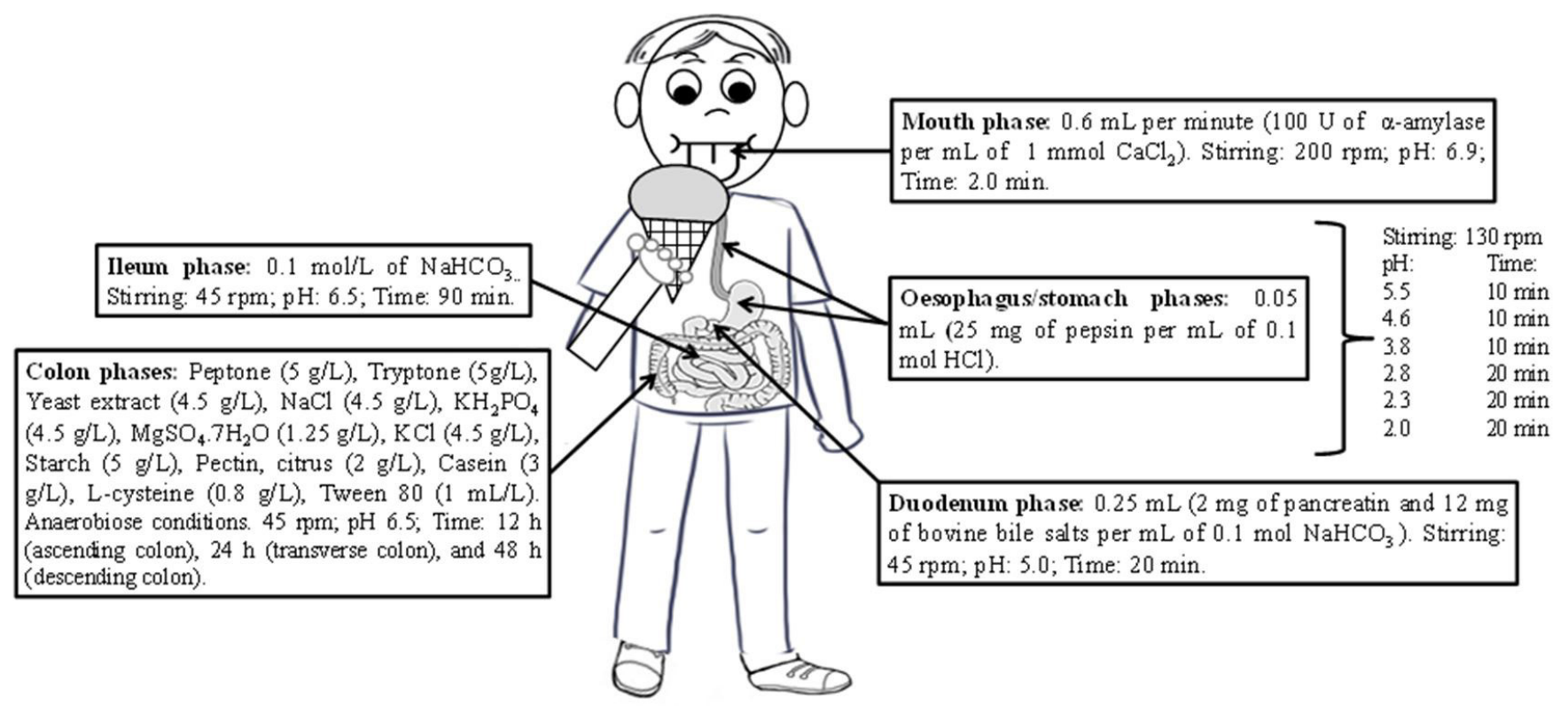

Figure 1. Protocol used during gastrointestinal in vitro digestion phases. 
a)

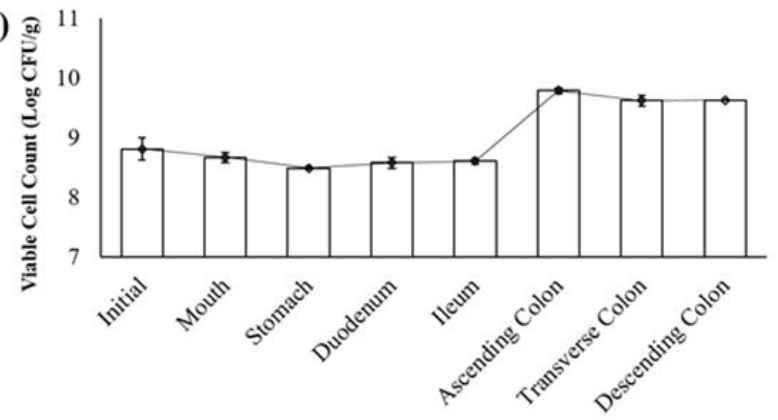

b)

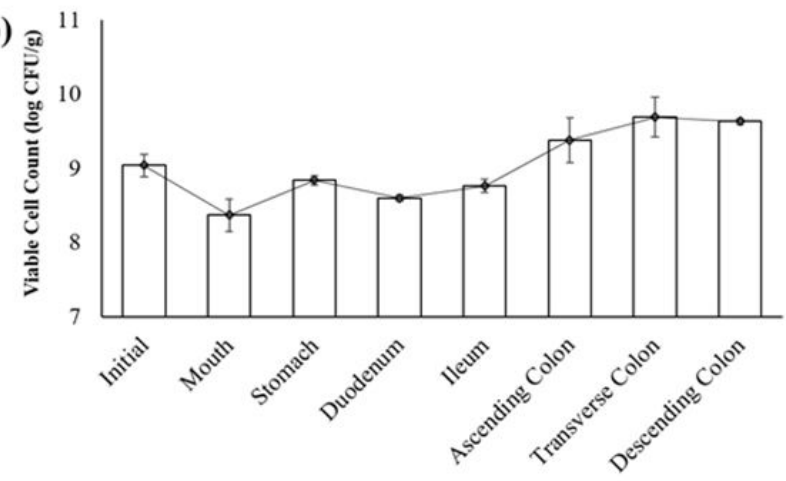

c)

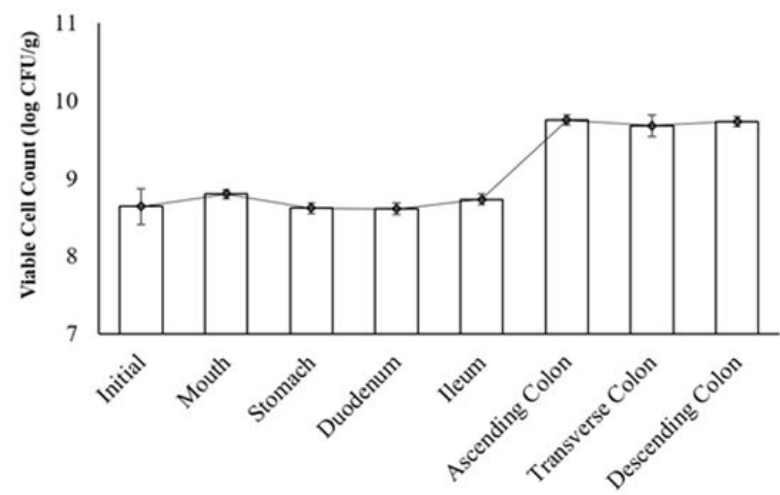

Figure 2. Bifidobacterium BB-12 viable cells count data mean from (a) control sample (MRS broth); (b) ice cream 1 sample, prepared with whole milk; and (c) ice cream 2 samples, using concentrated whey, after exposure to each one gastrointestinal in vitro digestion phase. The bars represent the standard deviation (I). gastrointestinal homeostasis by positively affecting the intestinal microbiota balance. Akalin et al. (2018) and Kozłowicz et al. (2019) classified the ice cream as a great product to be used as a probiotic vehicle because of its stability in frozen systems and its composition that includes proteins, fat and lactose. Kozłowicz et al. (2019) also stated that the ice cream pH is higher than fermented milk's, which has a positive impact on probiotic bacteria's survival. Soares et al. (2019) confirmed that species of the genus Bifidobacterium are notoriously more sensitive to acid (4.5-5.0) and alkaline $\mathrm{pH}$ (8.0-8.5) foods. Silva et al. (2015) affirmed that the aeration and freezing of the ice cream mix can lead to serious damage to bacterial cells. However, these authors also stated that the use of an appropriate inoculum amount of the probiotic bacterial strain can contribute to high bacterial abundance. Other factors involved in maintaining probiotic viable cell counts could be related to the ice cream mix composition. Rodrigues et al. (2019) reported that milk is currently the main probiotic vehicle used by the food industry worldwide. Silva et al. (2015) verified that goat's milk ice cream was an adequate delivery vehicle for bifidobacteria.

Madureira et al. (2011) affirmed that probiotic bacteria's behavior in MRS broths provides an excellent base for comparison, evaluating different ice cream compositions' protective effects. Therefore, in this study, it was verified that ice cream 2 samples (made of concentrated whey) demonstrated to be a great probiotic vehicle. Yasmin et al. (2019) also observed a protective effect of Bifidobacterium longum BL-05 in simulated gastrointestinal conditions, using whey proteins mixes. These authors concluded that such protective effect was due to the abundance of specific amino acid residues from whey that provides a protective environment for probiotics. Etchepare et al. (2020) noted that the buffering effect presented by higher whey protein presence contributed to higher rates of probiotics survival during gastrointestinal tests. These authors also observed that the use of whey proteins provided substantially better protection for probiotic bacteria Lactobacillus acidophilus La-14. Therefore, it was expected that, if probiotics are incorporated into the food system, they should remain stable during the processing of the food until consumption. Furthermore,

Table 1. Bifidobacterium BB-12 survival rate (\%) results expressed as mean \pm standard deviation, after exposure to each gastrointestinal in vitro phase from control (MRS broth), ice cream 1 (with whole milk), and ice cream 2 (with concentrated whey) samples.

\begin{tabular}{|c|c|c|c|c|}
\hline \multirow{2}{*}{\multicolumn{2}{|c|}{ Phase }} & \multicolumn{3}{|c|}{ Sample } \\
\hline & & Control & Ice cream 1 & Ice cream 2 \\
\hline \multicolumn{2}{|l|}{ Mouth } & $98.36 \pm 0.90^{\mathrm{cB}}$ & $92.63 \pm 2.46^{\mathrm{dC}}$ & $101.85 \pm 0.70^{\mathrm{bA}}$ \\
\hline \multicolumn{2}{|l|}{ Esophagus/Stomach } & $96.34 \pm 0.22^{\mathrm{dC}}$ & $97.88 \pm 0.68^{\mathrm{bB}}$ & $100.03 \pm 0.86^{\mathrm{b}, \mathrm{cA}}$ \\
\hline \multicolumn{2}{|l|}{ Duodenum } & $97.40 \pm 0.99^{\mathrm{c}, \mathrm{dB}}$ & $95.17 \pm 0.44^{\mathrm{c}, \mathrm{dC}}$ & $99.67 \pm 0.86^{\mathrm{cA}}$ \\
\hline \multicolumn{2}{|l|}{ Ileum } & $97.73 \pm 0.52^{\text {св }}$ & $96.96 \pm 0.98^{\mathrm{b}, \mathrm{cB}}$ & $101.03 \pm 0.84^{\mathrm{b}, \mathrm{cA}}$ \\
\hline \multirow{3}{*}{ Colon } & Ascending & $111.08 \pm 0.56^{\mathrm{aB}}$ & $103.85 \pm 3.31^{\mathrm{aC}}$ & $112.79 \pm 0.68^{\mathrm{aA}}$ \\
\hline & Transverse & $109.11 \pm 1.04^{\mathrm{a}, \mathrm{bB}}$ & $107.25 \pm 3.04^{\mathrm{aB}}$ & $112.04 \pm 1.67^{\mathrm{aA}}$ \\
\hline & Descending & $109.25 \pm 0.13^{\text {ьв }}$ & $106.56 \pm 0.39^{\mathrm{aC}}$ & $112.57 \pm 0.74^{\mathrm{aA}}$ \\
\hline
\end{tabular}

$\mathrm{A}, \mathrm{B}, \mathrm{C}$ Within a row, different superscript uppercase letters denote significant differences $(P<0.05)$ between samples among the same step of the gastrointestinal in vitro phase. ${ }^{\mathrm{a}, \mathrm{b}, \mathrm{c}, \mathrm{d}, \mathrm{W}}$ ithin a column, different superscript lowercase letters denote significant differences $(P<0.05)$, for the same sample among the different steps of the gastrointestinal in vitro phase. 
it was also expected that orally ingested probiotics should survive the harsh acidic condition of the gastrointestinal tract, overcoming the upper digestive tract to reach the colon. For this reason, this study aimed on evaluating Bifidobacterium BB-12's survival rate under in vitro simulated gastrointestinal environments, when incorporated into milk and concentrated whey ice cream mixes. The addition of Bifidobacterium BB12 into the ice creams and in vitro processing was realized sequentially, accordingly to the established by our research group. However, in the present work, the innovation is also related to further studies on colon's background, where samples were collected after $12 \mathrm{~h}$ (ascending colon), $24 \mathrm{~h}$ (transverse colon) and $48 \mathrm{~h}$ (descending colon).

The passage through the gastrointestinal tract includes different challenges for bifidobacteria added into MRS broth, ice cream 1 and ice cream 2 samples. Overall, it was noticed bifidobacteria's survival rates remained high (>90\%) (Table 1) on all samples and through mouth, esophagus and stomach, duodenum and ileum stages. High Bifidobacterium BB-12's survival rates found in all samples could be related to this microorganism's gene coding for bile salt hydrolase, an enzyme responsible for coping with high bile salt concentrations in the small intestine. This enzyme is always present and active in Bifidobacterium BB-12, as described by Jungersen et al. (2014). Sánchez et al. (2007) stated that studies with Bifidobacterium BB-12 indicated several genes involved in fatty acid biosynthesis were down-regulated in the presence of bile salts and suggested that bile salts could induce changes in bifidobacteria's cytoplasmic membrane composition. These authors also revealed that bifidobacteria's metabolic reorganization is also correlated to changes in the preferential branch through glycolytic pathway, and hence in the manner of energy production. Sánchez et al. (2007) also cited others changes of bifidobacteria which are associated with its resistance after exposure to gastrointestinal conditions, such as the occurrence of the fatty acid biosynthesis; the increase of molecular chaperones amount; the modification of cell 's redox balance and; the nitrogen metabolism, which could be involved with a sigma factor. Zhang et al. (2019) reported that the sigma factor is responsible for the major gene transcription that allows bacteria to respond to environmental changes. According to these authors, sigma factors are multi-domain subunits of bacterial RNA polymerase, which plays vital roles in the transcription initiation process and has great effects on many important cellular activities, such as growth and stress tolerance, considering environmental changes. However, it should be pointed out that the best bifidobacteria survival rate's performance $(P<0.05)$ was found in ice cream 2 . This confirms that, even though well-equipped to endure this critical passage in the gastrointestinal tract, Bifidobacterium BB-12 may suffer several damages, resulting in a survival rate decrease, as verified by Muñoz et al. (2018b). As in our study, these authors also identified a better bifidobacteria protective effect in soft fresh cheese from freeze concentrated milk, and therefore, containing more cheese whey protein when compared to MRS broth. This leads to believe that the increase of total solids due to the whey proteins in the ice cream sample was responsible for a more stable and protective food matrix for bifidobacteria. Tamime et al. (2006) reported that the addition of whey proteins increases the buffering capacity, contributing to a better survival rate of probiotic microorganisms. Because these authors emphasized that the freezing stress during ice cream production must be considered as a limiting factor for probiotic survival rate, we also consider that bifidobacteria's protective effect is related to the concentrated whey used on the elaboration of ice cream 2.

Just like the probiotic's survival in the presence of gastric acid and bile from the upper gastrointestinal tract is critical, it is also crucial for bifidobacterias survival in the colon (large intestine). Jungersen et al. (2014) affirmed that the human large intestine presents a wide variety of bacteria, with bifidobacterias being prominent members of this complex ecosystem. Presumably, Hadad et al. (2019) stated that the reduction in oxygen levels from colon stages enables anaerobic bacteria like bifidobacteria to grow. This was confirmed in this study and is demonstrated by the highest $(P<0.05)$ bifidobacteria survival rate (Table 1$)$ detected in colon stages (ascending, transverse, descending). Shu et al. (2020) observed an increase in probiotic survival rate when the environment changes went from strong acid to a suitable one $(\mathrm{pH} \geq 6)$. These same authors assert that the cause of this increase is associated with an acidic environment. In this case, probiotics strengthen its cell walls and the cell membrane permeability changes. Therefore, the $\mathrm{H}+$ is isolated outside of the cells, protecting them, which is an important reaction promoted by bacteria in acidic environments considering DNA's damage repair and acid-induced protein (Shu et al., 2020). It is noteworthy that probiotic effects depend on the intestinal viability and physiological activity after the probiotic passage and survival against gastric and biliary acids from upper gastrointestinal tract. Therefore, the use of concentrated whey obtained by a non-thermal and cheaper process (block freeze concentration) as a Bifidobacterium BB-12 matrix protection increased the ice cream's functional value, since this specific probiotic bacteria showed a higher survivability under in vitro simulated gastrointestinal environments in comparison to milk-based ice cream.

\section{Conclusion}

Both milk and concentrated whey ice creams presented high amounts of bifidobacterial viable cell counts after exposure to in vitro simulated gastrointestinal environments, overtaking the recommendation for probiotic products. The Bifidobacterium BB-12 added to the ice creams showed the most important characteristic of probiotic microorganisms, demonstrating the ability to survive through the upper digestive tract to reach the large intestine. Concentrated whey ice creams showed the best bifidobacteria protective effect after exposure to in vitro simulated gastrointestinal backgrounds, demonstrating great tolerance to environmental changes. Also, the higher total solids content of concentrated whey is mostly represented by proteins.

\section{Acknowledgements}

The authors are grateful to $\mathrm{CNPq}$ (National Council for Scientific and Technological Development, Brazil) for the financial support [CNPq, 405965/2016-8], and to CAPES (Coordination of Improvement of Higher Education Personnel, Brazil - Finance Code 001) by the scholarship. 


\section{References}

Aider, M., \& Halleux, D. (2008). Production of concentrated cherry and apricot juices by cryoconcentration technology. LebensmittelWissenschaft + Technologie, 41(10), 1768-1775. http://dx.doi. org/10.1016/j.lwt.2008.02.008.

Akalin, A. S., Kesenkas, H., Dinkci, N., Unal, G., Ozer, E., \& Kınık, O. (2018). Enrichment of probiotic ice cream with different dietary fibers: Structural characteristics and culture viability. Journal of Dairy Science, 101(1), 37-46. http://dx.doi.org/10.3168/jds.201713468. PMid:29103712.

Akbari, M., Eskandari, M. H., \& Davoudi, Z. (2019). Application and functions of fat replacers in low-fat ice cream: A review. Trends in Food Science \& Technology, 86, 34-40. http://dx.doi.org/10.1016/j. tifs.2019.02.036.

Balthazar, C. F., Silva, H. L. A., Esmerino, E. A., Rocha, R. S., Moraes, J., Carmo, M. A. V., Azevedo, L., Camps, I., K D Abud, Y., Sant'Anna, C., Franco, R. M., Freitas, M. Q., Silva, M. C., Raices, R. S. L., Escher, G. B., Granato, D., Senaka Ranadheera, C., Nazarro, F., \& Cruz, A. G. (2018). The addition of inulin and Lactobacillus casei 01 in sheep milk ice cream. Food Chemistry, 246, 464-472. http://dx.doi. org/10.1016/j.foodchem.2017.12.002. PMid:29291874.

Barretta, C., Verruck, S., Maran, B. M., Maurício, L. S., Miotto, M., Vieira, C. R. W., \& Prudencio, E. S. (2019). Listeria monocytogenes survival in raw Atlantic salmon (Salmo salar) fillet under in vitro simulated gastrointestinal conditions by culture, qPCR and PMAqPCR detection methods. Lebensmittel-Wissenschaft + Technologie, 107, 132-137. http://dx.doi.org/10.1016/j.lwt.2019.03.015.

Calligaris, S., Marino, M., Maifreni, M., \& Innocente, N. (2018). Potential application of monoglyceride structured emulsions as delivery systems of probiotic bacteria in reduced saturated fat ice cream. Lebensmittel-Wissenschaft + Technologie, 96, 329-334. http:// dx.doi.org/10.1016/j.lwt.2018.05.046.

Canella, M. H. M., Munoz, I. B., Pinto, S. S., Liz, G. R., Muller, C. M. O., Amboni, R. D. M. C., \& Prudencio, E. S. (2018). Use of Concentrated whey by freeze concentration process to obtain a symbiotic fermented lactic beverage. Advance Journal of Food Science and Technology, 14(2), 56-68. http://dx.doi.org/10.19026/ajfst.14.5832.

Champagne, C. P., Raymond, Y., Guertin, N., \& Bélanger, G. (2015). Effects of storage conditions, microencapsulation and inclusion in chocolate particles on the stability of probiotic bacteria in ice cream. International Dairy Journal, 47, 109-117. http://dx.doi.org/10.1016/j. idairyj.2015.03.003.

Etchepare, M. A., Nunes, G. L., Nicoloso, B. R., Barin, J. S., Flores, R. M. M., Mello, R. O., \& Menezes, C. R. (2020). Improvement of the viability of encapsulated probiotics using whey proteins. Lebensmittel-Wissenschaft + Technologie, 117, 108601. http://dx.doi. org/10.1016/j.lwt.2019.108601.

Fritzen-Freire, C. B., Prudêncio, E. S., Amboni, R. D. M. C., Pinto, S. S., Negrão-Murakami, A. N., \& Murakami, F. S. (2012). Microencapsulation of bifidobacteria by spray drying in the presence of prebiotics. Food Research International, 45(1), 306-312. http://dx.doi.org/10.1016/j. foodres.2011.09.020.

Góral, M., Kozłowicz, K., Pankiewicz, U., \& Góral, D. (2018). Magnesium enriched lactic acid bacteria as a carrier for probiotic ice cream production. Food Chemistry, 239, 1151-1159. http://dx.doi. org/10.1016/j.foodchem.2017.07.053. PMid:28873534.

Guo, Z., Wang, J., Yan, L., Chen, W., Liu, X., \& Zhang, H. (2009). In vitro comparison of probiotic properties of Lactobacillus casei Zhang, a potential new probiotic, with selected probiotic strains.
Lebensmittel-Wissenschaft + Technologie, 42(10), 1640-1646. http:// dx.doi.org/10.1016/j.lwt.2009.05.025.

Hadad, S. E., Zakareya, A., Al-Hejin, A., Aldahlawi, A., \& Alharbi, M. (2019). Sustaining exposure to high concentrations of bifidobacteria inhibits gene expression of Mouse's mucosal immunity. Heliyon, 5(12), e02866. http://dx.doi.org/10.1016/j.heliyon.2019.e02866. PMid:31890933.

Hausjell, J., Miltner, M., Herzig, C., Limbeck, A., Saracevic, Z., Saracevic, E., Weissensteiner, J., Molitor, C., Halbwirth, H., \& Spadiut, O. (2019). Valorisation of cheese whey as substrate and inducer for recombinant protein production in E. coli HMS174(DE3). Bioresource Technology Reports, 8, 100340. http://dx.doi.org/10.1016/j.biteb.2019.100340.

Hill, C., Guarner, F., Reid, G., Gibson, G. R., Merenstein, D. J., Pot, B., Morelli, L., Canani, R. B., Flint, H. J., Salminen, S., Calder, P. C., \& Sanders, M. E. (2014). The International scientific association for probiotics and prebiotics consensus statement on the scope and appropriate use of the term probiotic. Nature Reviews. Gastroenterology \& Hepatology, 11(8), 506-514. http://dx.doi. org/10.1038/nrgastro.2014.66. PMid:24912386.

Jungersen, M., Wind, A., Johansen, E., Christensen, J. E., Stuer-Lauridsen, B., \& Eskesen, D. (2014). The science behind the probiotic strain Bifidobacterium animalis subsp. lactis BB-12. Microorganisms, 2(2), 92-110. http://dx.doi.org/10.3390/microorganisms2020092. PMid:27682233.

Kozłowicz, K., Góral, M., Góral, D., Pankiewicz, U., \& BronowickaMielniczuk, U. (2019). Effect of ice cream storage on the physicochemical properties and survival of probiotic bacteria supplemented with zinc ions. Lebensmittel-Wissenschaft + Technologie, 116, 108562. http:// dx.doi.org/10.1016/j.lwt.2019.108562.

Liu, Z., Bhandari, B., \& Zhang, M. (2020). Incorporation of probiotics (Bifidobacterium animalis subsp. Lactis) into 3D printed mashed potatoes: Effects of variables on the viability. Food Research International, 128, 108795. http://dx.doi.org/10.1016/j.foodres.2019.108795. PMid:31955760.

Madureira, A. R., Amorim, M., Gomes, A. M., Pintado, M. E., \& Malcata, F. X. (2011). Protective effect of whey cheese matrix on probiotic strains exposed to simulated gastrointestinal conditions. Food Research International, 44(1), 465-470. http://dx.doi.org/10.1016/j. foodres.2010.09.010.

Menchik, P., \& Moraru, C. I. (2019). Nonthermal concentration of liquid foods by a combination of reverse osmosis and forward osmosis. Acid whey: A case study. Journal of Food Engineering, 253, 40-48. http://dx.doi.org/10.1016/j.jfoodeng.2019.02.015.

Muñoz, I. B., Rubio, A., Blanco, M., Raventós, M., Hernández, E., \& Prudêncio, E. S. (2018a). Progressive freeze concentration of skimmed milk in an agitated vessel: Effect of the coolant temperature and stirring rate on process performance. Food Science \& Technology International, 25(2), 150-159. http://dx.doi.org/10.1177/1082013218803263. PMid:30286622.

Muñoz, I. B., Verruck, S., Canella, M. H. M., Dias, C. O., Amboni, R. D. M. C., \& Prudêncio, E. S. (2018b). The use of soft fresh cheese manufactured from freeze concentrated milk as a novelty protective matrix on Bifidobacterium BB-12 survival under in vitro simulated gastrointestinal conditions. Lebensmittel-Wissenschaft + Technologie, 97, 725-729. http://dx.doi.org/10.1016/j.lwt.2018.08.009.

Petzold, G., Moreno, J., Lastra, P., Rojas, K., \& Orellana, P. (2015). Block freeze concentration assisted by centrifugation applied to blueberry and pineapple juices. Innovative Food Science \& Emerging Technologies, 30, 192-197. http://dx.doi.org/10.1016/j.ifset.2015.03.007. 
Prazeres, A. R., Carvalho, F., \& Rivas, J. (2012). Cheese whey management: a review. Journal of Environmental Management, 110, 48-68. http:// dx.doi.org/10.1016/j.jenvman.2012.05.018. PMid:22721610.

Remón, J., García, L., \& Arauzo, J. (2016). Cheese whey management by catalytic steam reforming and aqueous phase reforming. Fuel Processing Technology, 154, 66-81. http://dx.doi.org/10.1016/j. fuproc.2016.08.012.

Rodrigues, D., Sousa, S., Rocha-Santos, T., Silva, J. P., Sousa Lobo, J. M., Costa, P., Amaral, M. H., Pintado, M. M., Gomes, A. M., Malcata, F. X., \& Freitas, A. C. (2011). Influence of L-cysteine, oxygen and relative humidity upon survival throughout storage of probiotic bacteria in whey protein-based microcapsules. International Dairy Journal, 21(11), 869-876. http://dx.doi.org/10.1016/j.idairyj.2011.05.005.

Rodrigues, V. C. C., Silva, L. G. S., Simabuco, F. M., Venema, K., \& Antunes, A. E. C. (2019). Survival, metabolic status and cellular morphology of probiotics in dairy products and dietary supplement after simulated digestion. Journal of Functional Foods, 55, 126-134. http://dx.doi.org/10.1016/j.jff.2019.01.046.

Sánchez, B., Champomier-Vergès, M. C., Stuer-Lauridsen, B., RuasMadiedo, P., Anglade, P., Baraige, F., de los Reyes-Gavilán, C. G., Johansen, E., Zagorec, M., \& Margolles, A. (2007). Adaptation and response of Bifidobacterium animalis subsp. lactis to bile: a proteomic and physiological approach. Applied and Environmental Microbiology, 73(21), 6757-6767. http://dx.doi.org/10.1128/AEM.00637-07. PMid:17827318.

Saremnezhad, S., Zargarchi, S., \& Kalantari, Z. N. (2020). Calcium fortification of prebiotic ice-cream. Lebensmittel-Wissenschaft + Technologie, 120, 108890. http://dx.doi.org/10.1016/j.lwt.2019.108890.

Shu, G., Tian, M., Chen, L., Ma, D., Cui, X., \& Meng, J. (2020). Probiotic goat milk tablets: Formulation optimization and stability evaluation. Lebensmittel-Wissenschaft + Technologie, 119, 108862. http://dx.doi. org/10.1016/j.lwt.2019.108862.
Silva, P. D. L., Bezerra, M. F., Santos, K. M. O., \& Correia, R. T. P. (2015). Potentially probiotic ice cream from goat's milk: characterization and cell viability during processing, storage and simulated gastrointestinal conditions. Lebensmittel-Wissenschaft + Technologie, 62(1), 452-457. http://dx.doi.org/10.1016/j.lwt.2014.02.055.

Soares, M. B., Martinez, R. C. R., Pereira, E. P. R., Balthazar, C. F., Cruz, A. G., Ranadheera, C. S., \& Sant'Ana, A. S. (2019). The resistance of Bacillus, Bifidobacterium, and Lactobacillus strains with claimed probiotic properties in different food matrices exposed to simulated gastrointestinal tract conditions. Food Research International, 125, 108542. http://dx.doi.org/10.1016/j.foodres.2019.108542. PMid:31554104.

Tamime, A. Y., Saarela, M., Sndergaard, A. K., Mistry, V. V., \& Shah, N. P. (2006). Production and maintenance of viability of probiotic micro-organisms in dairy products. In A. Tamime (Ed.), Probiotic dairy products (pp. 39-72). Oxford: Blackwell Publishing. http:// dx.doi.org/10.1002/9780470995785.ch3.

Vinderola, C. G., \& Reinheimer, J. A. (2000). Enumeration of Lactobacillus case $i$ in the presence of $L$. acidophilus, bifidobacteria and lactic starter bacteria in fermented dairy products. International Dairy Journal, 10(4), 271-275. http://dx.doi.org/10.1016/S0958-6946(00)00045-5.

Yasmin, I., Saeed, M., Pasha, I., \& Zia, M. A. (2019). Development of whey protein concentrate-pectin-alginate based delivery system to improve survival of $B$. longum BL-05 in simulated gastrointestinal conditions. Probiotics and Antimicrobial Proteins, 11(2), 413-426. http://dx.doi.org/10.1007/s12602-018-9407-x. PMid:29572754.

Zhang, C., Zhang, W., Liang, W., Shao, Y., Zhao, X., \& Li, C. (2019). A sigma factor RpoD negatively regulates temperature-dependent metalloprotease expression in a pathogenic Vibrio splendidus. Microbial Pathogenesis, 128, 311-316. http://dx.doi.org/10.1016/j. micpath.2019.01.021. PMid:30660738. 